\title{
What is Lexicography?
}

Henning Bergenholtz, Department of Afrikaans and Dutch, University of Stellenbosch, Stellenbosch, Republic of South Africa and Centre for Lexicography, Aarhus University, Aarhus, Denmark (hb@asb.dk) and

Rufus H. Gouws, Department of Afrikaans and Dutch, University of Stellenbosch, Stellenbosch, Republic of South Africa (rhg@sun.ac.za)

\begin{abstract}
Within the field of lexicography there are numerous differences when it comes to the interpretation of the term lexicography and differences in determining the nature, extent and scope of this term. Although it is widely accepted that lexicography consist of two components, i.e. theoretical lexicography and the lexicographic practice, different definitions of lexicography give no unambiguous reflection of this distinction and of the individual components. This paper looks at some prevailing diverse uses and interpretations of the word lexicography. This is followed by proposals to ensure a transformative, unified and comprehensive interpretation of this concept.
\end{abstract}

Keywords: INDEPENDENT DISCIPLINE, INFORMATION TOOL, LEXICOGRAPHER, LEXICOGRAPHIC PRACTICE, LEXICOGRAPHIC THEORY, LEXICOGRAPHIC TOOL, LEXICOGRAPHY, LEXICOLOGY, METALEXICOGRAPHY, SCIENTIFIC LEXICOGRAPHY, TERMINOGRAPHY

Opsomming: Wat is leksikografie? In die leksikografie bestaan daar talle verskille met betrekking tot die interpretasie van die term leksikografie asook met betrekking tot 'n vasstelling van die aard, omvang en bestek van hierdie term. Alhoewel dit wyd aanvaar word dat leksikografie uit twee komponente bestaan, naamlik 'n teoretiese en 'n praktiese komponent, bied onderskeie definisies van leksikografie geen ondubbelsinnige beskrywing van hierdie verskil en van die onderskeie komponente nie. Hierdie artikel gee aandag aan enkele bestaande maar uiteenlopende gebruike en interpretasies van die woord leksikografie. Daarna volg voorstelle ter versekering van 'n transformatiewe verenigde en omvattende interpretasie van hierdie begrip.

Sleutelwoorde: INLIGTINGSWERKTUIG, LEKSIKOGRAAF, LEKSIKOGRAFIE, LEKSIKOGRAFIESE PRAKTYK, LEKSIKOGRAFIESE WERKTUIG, LEKSIKOGRAFIETEORIE, LEKSIKOLOGIE, METALEKSIKOGRAFIE, ONAFHANKLIKE DISSIPLINE, TERMINOGRAFIE, WETENSKAPLIKE LEKSIKOGRAFIE

\section{Introduction}

The first section of this paper indicates a number of definitions of lexicography as found in general sources, specialized dictionaries and scientific publications. 
These definitions reflect the prevailing interpretations of this term. It is clear that there are significant differences between some of the interpretations. In order to have a mutual point of departure when talking about lexicography the need is indicated for a unified explanation of lexicography. Subsequently this term is discussed in some detail, focusing on different components of lexicography. Taking cognizance of the existing definitions as well as the points raised in the preceding discussion suggestions are made for a new interpretation of the term that encompasses the majority of relevant features.

\section{Current views on lexicography}

When attempting to define a widely-used concept like lexicography it is important to take cognizance of some other existing definitions in order to detect some of the mutual strong and weak points. This section will refer to a few definitions and paraphrases of lexicography from three categories of sources, i.e. general sources (including general language printed dictionaries and results from random Google searches), LSP dictionaries dealing with lexicography and, thirdly, scientific discussions in the field of lexicography.

\subsection{Definitions in general sources}

The definitions or paraphrases given in general sources have to be regarded as important because that is where the non-expert in lexicography finds information regarding the meaning of this word. Someone looking for such a definition, especially those found in random Google searches, has no guarantee as to the authority of the definition or the expertise of the person who formulated it. The quality of these definitions shows significant differences, as can be seen in the following randomly selected examples:

\section{Definition no. 1}

the practice of compiling dictionaries (The New Oxford Dictionary of English)

This is an extremely unsatisfactory definition that makes no provision for the theoretical component and gives no details regarding the compilation process.

\section{Definition no. 2}

lexicography (is) the applied study of the meaning, evolution, and function of the vocabulary units of a language for the purpose of compilation in book form - in short, the process of dictionary making.

(http://answers.encyclopedia.com/question/lexicography-159511.html)

Although better than the first definition this definition also ignores reference to 
a theoretical component. Too strong a focus is placed on meaning - not all dictionaries include items giving the meaning of words.

\section{Definition no. 3}

Perhaps the simplest explanation of lexicography is that it is a scholarly discipline that involves compiling, writing, or editing dictionaries. Lexicography is widely considered an independent scholarly discipline, though it is a subfield within linguistics.

Many consider lexicography to be divided into two related areas. The act of writing, or editing dictionaries is known as Practical Lexicography. The analysis or description of the vocabulary of a particular language, and the meaning that links certain words to others in a dictionary, is known as Theoretical Lexicography. Theoretical Lexicography is particularly concerned with developing theories regarding the structural and semantic relationships among words in the dictionary. Since it involves theoretical analysis of the lexicon, Theoretical Lexicography is also known as Metalexicography.

(http://www.wisegeek.com/what-is-lexicography.htm)

A positive aspect of this definition is the distinction it makes between practical and theoretical lexicography. A negative aspect is that it regards lexicography as a subfield within linguistics.

\section{Definition no. 4}

Lexicography is divided into two related disciplines:

- Practical lexicography is the art or craft of compiling, writing and editing dictionaries.

- Theoretical lexicography is the scholarly discipline of analyzing and describing the semantic, syntagmatic and paradigmatic relationships within the lexicon (vocabulary) of a language, developing theories of dictionary components and structures linking the data in dictionaries, the needs for information by users in specific types of situation, and how users may best access the data incorporated in printed and electronic dictionaries. This is sometimes referred to as 'metalexicography'. (http:/ /en.wikipedia.org/wiki/Lexicography)

This is a fairly well-balanced definition. Reference to dictionaries as practical tools would have enhanced its quality.

\section{Definition no. 5}

Die maak van woordeboeke (The making of dictionaries) (Woordeboek van die Afrikaanse Taal)

This article for leksikografie in the Woordeboek van die Afrikaanse Taal has a crossreference to metaleksikografie where the following definition is found:

Teoretiese komponent v.d. leksikografie waarin die beginsels en tegnieke v.d. 
leksikografiese praktyk in oënskou geneem en daaroor besin word. (Theoretical component of lexicography which takes stock of the principles and techniques of the lexicographic practice and contemplates them.)

Two synonyms are then given for metaleksikografie (=metalexicography), i.e. leksikografieteorie (=lexicographic theory) and leksikologie (=lexicology).

Like definition 1, definition 5 is poor but the cross-reference to metalexicography does help. The definition of metalexicography is not bad but the user is illadvised by the item indicating that it has lexicology as synonym.

No definition was given to account for a frequently used reference to lexicography as being an art or a craft — as seen in the title of Landau (2001): Dictionaries: The Art and Craft of Lexicography - by explaining the nature of this art or craft, albeit that Definition 4 does refer to art or craft. In this paper we do not regard lexicography as an art or a craft albeit that specific skills and talents play an important role in the lexicographic practice. Definitions like 1, 2 and 5 make no distinction between practical and theoretical lexicography and from all these definitions no realistic interpretation of the nature and extent of lexicography is possible. No clarity can be found regarding the relation between lexicography on the one hand and, on the other hand, applied linguistics, lexicology, encyclopedology and terminology. In addition, conflicting comments are found regarding the status of lexicography as an independent discipline. Definition 2 refers to "applied study", definition 5 gives a cross-reference to metaleksikografie that has lexicology as a synonym. No definition makes a reference to the fact that dictionaries, as products of the lexicographic practice, cover both language for general purposes and language for special purposes. This defies the reality that LSP lexicography, often referred to as terminography, also falls within the scope of lexicography. The fact that dictionary typology makes provision for encyclopedic dictionaries, i.e. dictionaries that do not focus on the linguistic but rather the extra-linguistic features, does not come to the fore in any of the definitions. Definitions 3 and 4 make provision for theoretical and practical components of lexicography. The nature of the theoretical component is not clear at all although there is a focus on the analysis of dictionaries and, rightly so, on the development of theories. The independence of lexicography is indicated in definition 3 but the same definition contradicts itself by indicating that lexicography is a subfield within linguistics. The average language user who consults any one of these definitions, with the exception of definition no. 4 which gives a reasonably well-balanced account of lexicography, will have an incomplete knowledge of the word lexicography, and the user consulting any combination of these definitions will be confused. Clearly the definition of the word lexicography in a random selection of sources aimed at the non-expert is totally insufficient.

\subsection{Dictionaries of lexicography}

Specialized dictionaries of lexicography assist their users in a far better way. 
The Dictionary of Lexicography (Hartmann and James 1998) defines lexicography as:

The professional activity and academic field concerned with DICTIONARIES and other REFERENCE WORKS. It has two basic divisions: lexicographic practice, or DICTIONARY-MAKING, and lexicographic theory, or DICTIONARY RESEARCH. ...

It continues with a more comprehensive description of both divisions, including a listing of several branches of lexicography, e.g. author lexicography, bilingual lexicography, encyclopedic lexicography, specialized lexicography, thesaurus lexicography. By means of a diagram it divides dictionary research into four components, i.e. history, typology, criticism and use, whereas dictionary-making is divided into three components, i.e. fieldwork, description and presentation.

However, one misses remarks regarding the user, the contents, the structures and the functions of dictionaries and, in a dictionary described on the cover as a "professional handbook", a reference to different theories of lexicography.

In Lexicography: A dictionary of basic terminology (Burkhanov 1998) an extensive treatment of lexicography is found. The main issues referred to are the "disciplinary status of lexicography, its correlation with other linguistic and nonlinguistic disciplines, the scope of lexicographic description, methodology of lexicographic investigation, typology of reference works produced within the framework of lexicography, techniques of lexicographic presentation ..." Different perspectives on the position of lexicography are also given (with an indication of the relevant literature; not repeated here): "Lexicography is regarded as a domain of applied linguistics ..., a branch of information science ..., a province of philological and historical study ..., a subject field whose theoretical aspect falls within the realm of theoretical linguistics, whereas its practice pertains to the sphere of applied linguistics ...". Burkhanov also refers to the fact that "lexicography has been successfully developing its own theory." He also argues that "The term 'lexicography' refers to the process, result, and theoretical evaluation, of the making of reference works which represent a wide range of heterogeneous knowledge structures ...".

Burkhanov's description allows the expert user a comprehensive retrieval of information and gives ample guidance in terms of the extent of information transfer in a dictionary. However, the important role of the user and the really important notion of lexicography as an independent discipline does not come to the fore strongly enough. ${ }^{1}$

\subsection{Scientific discussions}

Whereas the above-mentioned specialized dictionaries of lexicography agree on lexicography having both a practical and a theoretical component, one of the first crucial issues in the discussions of lexicography as found in scientific publications is whether the notion of a theory of lexicography is accepted or 
not. Different approaches prevail, ranging from Atkins and Rundell (2008: 4) saying, with regard to a theory of lexicography, that they "do not believe that such a thing exists", and Bejoint (2010: 381) saying: "I simply do not believe that there exists a theory of lexicography, and I very much doubt that there can be one", to lexicographers who firmly believe in a lexicographic theory, cf. Wiegand (1989), Bergenholtz and Tarp (2003), Gouws (2011), Tarp (2012). It is important to note that the supporters of a lexicographic theory do not all adhere to the same theory: there are different lexicographic theories but they all acknowledge the fact that the lexicographic practice is complemented by a theoretical component and that lexicography, with dictionaries as its subject matter, should be regarded as an independent discipline.

Wiegand (1984: 13) categorically denies that lexicography is a branch of applied linguistics or of lexicology, but when working outside a specific lexicographic theory, relations between lexicography and other disciplines are often postulated that go against the grain of lexicography as an independent discipline, cf. Kempcke (1982: 44) who says "Eine Wörterbuchtheorie kann nur Teil der Lexikologie sein, ..." (A dictionary theory has to be part of lexicology). Lexicographers like Urdang (1963: 594) believe that "Lexicography, in practice is a form of applied linguistics ..." and Sinclair (1984: 7) denies the prospect of a theory of lexicography and believes that the relevant theory is to be found in or via the areas of linguistics and information technology. Geeraerts (1987: 1) assumes that lexicography is part of linguistics but can hardly justify it as being a form of applied linguistics:

As a linguistic discipline, lexicography has rather paradoxical nature. On the one hand, almost everybody will agree to classify lexicography as a form of applied linguistics, but on the other hand, it is virtually impossible to give an adequate reply to the question what linguistic theory lexicography might be an application of.

Some terminologists make a distinction between terminography and lexicography whilst lexicographers adhering to an inclusive lexicographic theory that makes provision for general and specialized lexicography regard specialized or LSP lexicography and terminography as synonyms, cf. Bergenholtz (1995b) and Bergenholtz and Kaufmann (1997). ${ }^{2}$

Tarp (2008: 9-10) distinguishes different types of theory in terms of three sets of distinctions, i.e. general and specific theories, integrated and non-integrated theories and contemplative and transformative theories. This last distinction is important for the present discussion. A purely contemplative approach only observes existing dictionaries and theoretical models and is rarely if ever put to practice. A transformative approach is innovative and this type of theory does not only interpret and explain lexicographic practice but it transforms it, cf. Tarp (2008: 10).

Within scientific discussions major differences also prevail regarding the scope of lexicography. In the introductory section to the first volume of the 
International Journal of Lexicography (IJL) Robert Ilson, the first editor of this journal, gave an indication of the scope the newly established journal would like to cover - a scope that should reflect a specific interpretation of what lexicography is all about. Ilson (1988) says:

IJL is devoted to examining how people inform one another. In its pages are discussed which items are selected to give information about, what information is given about them, and how that information is used. Our primary concern is with reference works that give lexically relevant information about lexically relevant items. But we realise that the problems facing compilers and users of dictionaries and thesauruses are similar to those facing compilers and users of indexes, encyclopaedias, atlases, and other types of reference work, and our pages are open to the discussion of their problems, too.

This broad scope which Ilson identifies, coincides with current theories pleading for a wider interpretation of the scope of lexicography, cf. Fuertes-Olivera and Bergenholtz (2011).

Engelberg and Lemnitzer (2009: 3) also distinguish between the lexicographic practice, i.e. the cultural practice aimed at the production of dictionaries, and the theoretical domain, directed at lexicography and dictionaries. They clearly state that theoretical lexicography is not part of applied linguistics. According to them lexicography has the following topics as subject matter:

the structure of dictionaries

the compilation of dictionaries (i.e. lexicography in the actual sense of the word)

the use of dictionaries (including aspects of didactics of dictionary use)

dictionary criticism

the history of lexicography.

Here one misses a reference to lexicographic functions. Looking at these diverse and often conflicting interpretations of lexicography this paper works with the assumption that lexicography has a theoretical and a practical component, that different lexicographic theories do exist, and that lexicography is an independent discipline. This point of departure leads to the formulation of a unified and more comprehensive explanation of lexicography.

\section{A unified and comprehensive approach}

The proposals in this paper should be seen in combination with the concurrently written papers of Bergenholtz (2012) and Gouws (2012). Some of the arguments given in these two papers are presupposed in the current paper. The proposals made here are based on and expands the dictionary article of the 
lemma leksikografi in the Nordic dictionary of lexicography, Bergenholtz et al. (1997).

There are two types of lexicography:

1. The development of theories about and the conceptualization of dictionaries, specifically with regard to the function, the structure and the contents of dictionaries. This part of lexicography is known as metalexicography or theoretical lexicography.

2. The planning and compilation of concrete dictionaries. This part of lexicography is known as practical lexicography or the lexicographic practice.

As seen in the previous sections there is a definite confusion in the metalexicographic discussion regarding the scope of lexicography and the borders with and relations to other disciplines. As previously remarked we regard lexicography as an independent discipline that does show some relation to parts of different other disciplines, e.g. information science and linguistics.

Our approach is not the only one; many people regard lexicography not as an independent discipline but as part of linguistics. Other people see parts of what we regard as lexicography as terminography or encyclopedology. We do not agree with this approach. More detailed motivation can be found in Bergenholtz (1995a) and a brief account thereof in the following paragraph.

In particular we do not see lexicography as part of lexicology - as is the case with some linguists and lexicographers, cf. paragraph 2.3. An approach that sees lexicographic theory as part of lexicology implies that lexicography puts the questions whereas lexicology provides the answers. We do not believe that this is the case in real practical situations. In contrast to their argument it is a fact that many lexicologists exclusively use data from dictionaries in their discussions. In the exact opposite way we regard the relation of terminography to that section of terminology where practical terminology prevails. Contrary to terminologists we regard terminography and subject field lexicography as synonym expressions. They have the same object and aims: to describe specialized fields so that specific information needs of the user can be satisfied, cf. Bergenholtz (1995b).

There also is a series of special types of lexicography, e.g. linguistic lexicography, subject field lexicography or corpus lexicography. We don't regard all the prevailing subtypes as necessary or beneficial to lexicography. However, this will not be discussed in detail here.

Linguistic lexicography is usually understood as general language lexicography that needs to achieve communicative functions. Subject field lexicography is typically understood as the monolingual lexicography of different subject fields, where the lexicography needs to achieve a cognitive function. Finally, encyclopedic lexicography is the type of lexicography that includes both linguistic and subject field lexicography. 
Lexicography is also identified in terms of the number of object languages: monolingual, bilingual or polylingual lexicography. In addition lexicography is used as part of a compound term when referring to the source material, e.g. corpus lexicography. But we have never encountered such terms as informant lexicography or citation lexicography although they could have been constructed accordingly. When the technical aids are put in the centre one refers to e.g. computational lexicography. When focusing on the purpose of the lexicography one talks about e.g. learner lexicography or translation lexicography. Finally the aim of lexicography becomes the documentation of a specific part of language use for future generations by having expressions like usage lexicography, i.e. the lexicography that accounts for concrete communicative, cognitive interpretative or operational needs, or documentation lexicography, that endeavours to solve a national or a general scientific problem.

There are further distinctions of this type and additional ones can be constructed. Our proposal is not directly related to that. We would rather try to present a general identification of lexicography.

The discussion of some definitions of lexicography in the first section of this paper already gives an answer to the question formulated in the title of this paper: Lexicography is the discipline dealing with theories about recently completed and also older existing dictionaries but also about future dictionaries as planned and produced by lexicographers. This simple answer is at the same time right but also too simple. There are different kinds of dictionaries and of lexicographers. This means e.g. that we have a type of lexicography describing, criticizing and making theories outgoing from existing dictionaries, and we have a type of lexicography making theories about how to plan and how to make conceptions for new dictionaries. And we have a branch of lexicography dealing with the concrete conception, planning and editing of a dictionary. Such a conception could be made without any kind of scientific considerations, i.e. by trying to make a new dictionary according to the way of "how it used to be" - the lexicographer makes a dictionary following his/her intuition and by knowing the needs of the intended user. Dictionaries of this type do not necessarily have a low quality, especially if they do not merely copy the "tradition". A splendid example of a dictionary belonging to this type was that of Leth (1800), a priest well familiar with the needs of the young people he was teaching, but not with the then current tradition of making conceptualisations of dictionaries. Another type of lexicography is totally influenced by linguistics and tries to use the best linguistic theories and terms for the planning and compilation of dictionaries. A final type of lexicography argues that lexicography is an independent discipline, perhaps somehow connected to a certain kind of information science or linguistics, but indeed not a subdiscipline of linguistics. Some aspects of these different types of approaches are illustrated in the following figure: 


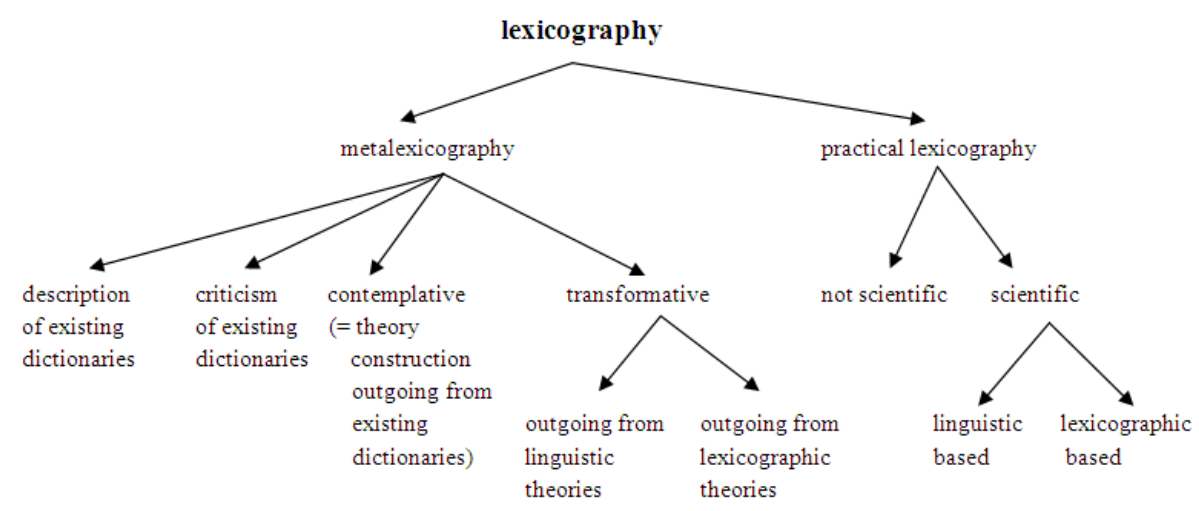

This figure does not show the real dilemma in lexicography. Most lexicographers claim that lexicography is a subdiscipline of linguistics. We do not think so. There are relations to linguistics but also to information science although we realise that, as in the case of lexicography, there are different opinions and definitions of what information science is. For the time being we therefore regard lexicography as an independent discipline, relying on experts coming from different disciplines. In one kind of dictionary the experts are linguists. This is the type of dictionary with the most relevance to linguistics of course. The following figure indicates different approaches regarding the object and functions of lexicography:

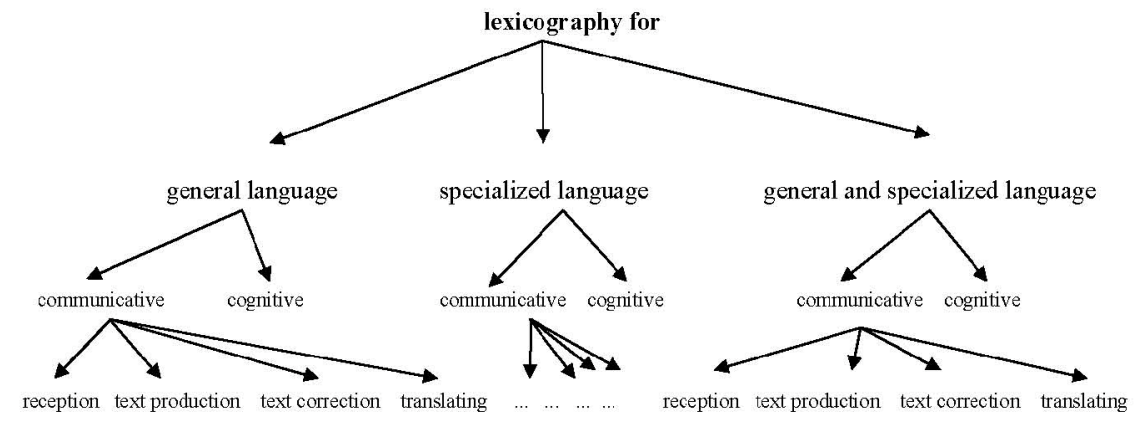

Traditionally lexicography had as its main object to deal with communicative information tools for general language dictionaries. We find this a too narrow understanding of lexicography that eschews many very important information tools. We regard lexicographic theory as a discipline not only directed at the production of dictionaries, but in a more general way at the production of information tools. The transformative approach can produce new ideas to ensure theoretically-based products, i.e. better dictionaries and other reference and information tools, and can ensure enhanced information retrieval. 


\section{Endnotes}

1. The Wörterbuch zur Lexikographie und Wörterbuchforschung/Dictionary of Lexicography and Dictionary Research will not be discussed here because the published volume has not yet reached the article stretch in which lexicography falls. The treatment of lexicography in the Nordisk leksikografisk ordbok will form a basis of the discussion in paragraph 3.

2. A variety of citations from different authors, reflecting on the diversity in interpretations when it comes to the term lexicography can be found in Tarp (2012) and Wiegand (1998: 13-47).

\section{References}

Atkins, B.T.S. and M. Rundell. 2008. The Oxford Guide to Practical Lexicography. Oxford/New York: Oxford University Press.

Béjoint, H. 2010. The Lexicography of English. Oxford: Oxford University Press.

Bergenholtz, H. 1995a. Leksikografi. Hvad er det? Svararsdóttir, Åsta, Gudrun Kvaran and Jón Hilmar Jónsson (Ed.). 1995. Nordiske studier i leksikografi 3. Rapport fra Konference om leksikografi i Norden. Reykjavik 7-10. juni 1995: 37-49. Reykjavik: Nordisk forening for leksikografi.

Bergenholtz, H. 1995b. Wodurch unterscheidet sich Fachlexikographie von Terminographie? Lexicographica 11: 37-46.

Bergenholtz, H. 2012. What is a Dictionary? Lexikos 22: 20-30.

Bergenholtz, Henning, Ilse Cantell, Ruth Vatvedt Fjeld, Dag Gundersen, Jón Hilmar Jónsson, and Bo Svensén. 1997. NLO. Nordisk leksikografisk ordbok. Oslo: Universitetsforlaget.

Bergenholtz, Henning and Uwe Kaufmann. 1997. Terminography and Lexicography. A Critical Survey of Dictionaries from a Single Specialised Field. Tarp, S. (Ed.). 1997. Specialised Lexicography and Terminology. Hermes 18: 91-125.

Bergenholtz, Henning and Sven Tarp. 2003. Two Opposing Theories: On H.E. Wiegand's Recent Discovery of Lexicographic Functions. Hermes, Journal of Linguistics 31: 171-196.

Burkhanov, Igor. 1998. Lexicography: A Dictionary of Basic Terminology Rzeszów: Wydawnictwo Wyższej Szkoły Pedagogicznej Rzeszów.

Engelberg, Stefan and Lothar Lemnitzer. 2009. Lexikographie und Wörterbuchbenutzung. Tübingen: Stauffenburg Verlag.

Fuertes-Olivera, Pedro A. and H. Bergenholtz (Eds.). 2011. e-Lexicography: The Internet, Digital Initiatives and Lexicography. London/New York: Continuum.

Geeraerts, D. 1987. Types of Semantic Information in Dictionaries. Ilson, R. (Ed.). 1987. A Spectrum of Lexicography: Papers from AILA, Brussels 1984: 1-10. Amsterdam: John Benjamins.

Gouws, R.H. 2011. Learning, Unlearning and Innovation in the Planning of Electronic Dictionaries. Fuertes-Olivera, Pedro A. and H. Bergenholtz (Eds.). e-Lexicography: The Internet, Digital Initiatives and Lexicography: 17-29. London/New York: Continuum.

Gouws, R.H. 2012. Who can Really be Called a Lexicographer? Lexikos 22: 217-225.

Hartmann, R.R.K. and Gregory James. 1998. Dictionary of Lexicography. London/New York: Routledge.

Ilson, R. 1988. Introduction. International Journal of Lexicography 1(1): ii. 
Kempcke, G. 1982. Lexikologie, lexikographische Theorie und lexikographische Praxis. Agricola, E. et al. (Eds.). 1982. Wortschatzforschung heute: 42-61. Leipzig: VEB Verlag.

Landau, S.I. 2001. Dictionaries: The Art and Craft of Lexicography. Second Edition. New York/Cambridge: Cambridge University Press.

Leth, J. 1800. Dansk Glossarium. En Ordbog til Forklaring over det danske Sprogs gamle, nye og fremme Ord og Talemaader for unge Mennesker og for Ustuderede. Et Forsøg. Med en Fortale af Professor Rasmus Nyerup. Kiøbenhavn: Trykt paa Hofboghandler Simon Poulsens Forlag hos Bogtrykker Morthorst's Enke \& Comp.

Pearsall, J. (Ed.). 1998. The New Oxford Dictionary of English. Oxford: Oxford University Press.

Sinclair, J.M. 1984. Lexicography as an Academic Subject. Hartmann, R.R.K. (Ed.). 1984. LEXeter '83 Proceedings: 3-12. Tübingen: Max Niemeyer.

Tarp, Sven. 2008. Lexicography in the Borderland between Knowledge and Non-knowledge. General Lexicographical Theory with Particular Focus on Learner's Lexicography. Lexicographica. Series Maior 134. Tübingen: Max Niemeyer.

Tarp, S. 2012. Do We Need a (New) Theory of Lexicography? Lexikos 22: 321-332.

Van Schalkwyk, D.J. (Ed.-in-chief). 1994. Woordeboek van die Afrikaanse Taal. Volume IX. Stellenbosch: Bureau of the WAT.

Van Schalkwyk, D.J. (Ed.-in-chief). 1996. Woordeboek van die Afrikaanse Taal. Volume X. Stellenbosch: Bureau of the WAT.

Urdang, L. 1963. Review: Problems in Lexicography: Report of the Conference on Lexicography. Language 39(3): 586-594.

Wiegand, H.E. 1984. On the Structure and Contents of a General Theory of Lexicography. Hartmann, R.R.K. (Ed.). 1984. LEXeter '83 Proceedings. Papers from the International Conference on Lexicography at Exeter, 9-12 September 1983: 13-30. Lexicographica. Series Maior 1. Tübingen: Max Niemeyer Verlag.

Wiegand, H.E. 1989. Der gegenwärtige Status des Lexikographie und ihr Verhältnis zu anderen Disziplinen. Hausmann, F.J. et al. (Eds.). 1989-1991. Wörterbücher. Ein internationales Handbuch zur Lexikographie: 246-280. Berlin/New York: Walter de Gruyter.

Wiegand, H.E. 1998. Wörterbuchforschung. Berlin: Walter de Gruyter. 